\title{
Moderate Islamic Character Education In 4.0 Industrial Era
}

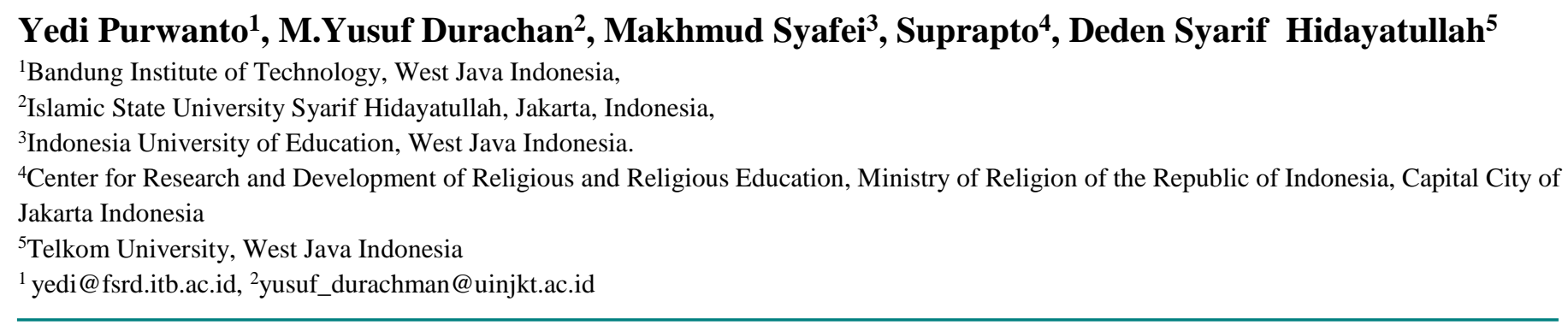

\section{ABSTRACT}

Character education build the moral of students based on ethics and national culture that has been internalized and becomes a special trait of the Indonesian nation. Through Islamic education, moderate character values will embrace human activities, both in the vertical or horizontal connection. This study aims to find out about the character education and the outcome, implemented at the Indonesia University of Education. Methodology of research are used quantitative and qualitative factor and participated by general mandatory courses (GMC) higher education students and graduates. The results indicated that Islamic character education have an important role to develop character of students.

Keywords

Moderate, Islamic, Characters Education, Higher Education, Industrial 4.0 Era.

Article Received: 10 August 2020, Revised: 25 October 2020, Accepted: 18 November 2020

\section{Introduction}

A moral decadence caused by drug trafficking, extremism, free-sex, intolerance, number of unemployment, and other destructive behavior will harm the harmonious lives of the nation and state. To avoid these hazardous events, the excellent generation should be prepared. Students especially in higher education, as the next generation of the nation, require a good education related to religious study, moral, and character to support national development.

The characters education was included in the general mandatory courses (GMC) through religious education (e.g. Islamic education), Pancasila and citizenship education, and Indonesian language (Syafei, et al., 2018). Characters education are dynamic and most deeply rooted in an environment of young generations as education for a very long period. Furthermore, character education consists of a comprehensive field of study consisting of theory, interdisciplinary research between educational disciplines, philosophy, psychology, and sociology (Pattaro, 2016). To prepare future leaders it is necessary to learn the character values of the past generations as a bridge in building future generations (Muqowim, 2019).In Indonesian nation, morals are a concept of national character which are composed in two aspects, such as autonomy and heteronomy. Autonomy is carried out through education in the form of teaching, habituation, modeling, motivation and enforcement. Heteronomy are carried out by the environment, with the application of social justice, economics, law enforcement, example, the regularity of social norms (Ris'an et al., 2019).

The continuing of the character values must consider to the good practiced in the society, not the vice versa. There are at least 10 signs of human behavior that lead to the demise of a nation, which are increasing violence; entrenching dishonesty; increasing disrespect to parents, teachers, and figures; group against violence; increasing suspicion and resentment; use of worsening language; decrease in work ethic; declining sense of individual responsibility and citizens; heightened self-destructive and behavior; and blurring of moral guidelines (Lickona, 1991).The ten criteria as alluded, if examined carefully, are analogous to the current structure of the Indonesian nation's life which being hit by crises in various fields, aspects, and even elements 
of life. One of the real crises happening is a moral decadence among the youths. For battling the crises, the first precept of Pancasila which is belief to the Almighty God, it should be a moral foundation and guidance for all components of this nation and state, including to higher education.

Islamic religious education in tertiary institutions is essentially needed. This is included under the GMC. GMC intends to provide foundation for students to care about social problems that occur in the environment and eventually they can solve these problems by using a basic socio-cultural science approach. As mandated by the Republic of Indonesia's National Education System Law number 20/2003 that the purpose of education in Indonesia is directed to shape the character of each student based on the religious teaching, fervor to the Almighty God (Republik Indonesia, 2003). As one form of realization of the act, integration is an alternative way that must be chosen hence education is more holistic.

In line with the Law number 12/2012 article 3, the principles of education which are scientific truth, honesty reasoning, justice, benefits, virtues, responsibilities, unity in diversity and affordability, relating to this, then, the education of religion, Pancasila and citizenship, and Indonesian language has a very important role to strengthening the higher education in Indonesia (Republik Indonesia, 2012). This urgency is triggered by many experts experienced with specialized and in-depth expertise, but their characters and national insights are narrow. This is due to the character education based on religion and precepts in Pancasila as well as the nation's culture has not been internalized by them.

Studies related to moderate character education have been performed by several researchers. The importance of instilling students' internal trust in completing learning tasks (Jaafar, 2018). This means that the teacher has the additional task of assisting students outside school hours in achieving their excellence and achievement. Furthermore, the Islamic Education actually taught in higher institutions is an internalization of the values of teaching moderation that gives students an understanding that Islam is a has the mission of "Rahmatan lil 'Alamin" or grace for the entire universe (Purwanto et al., 2019). Islam as a character and morals educates students to be tolerant, harmonious, respect for differences, innovative in spirit, like to help others, independent in spirit, and devoted to the Almighty God. Also, the influence of religion on the values of work in the European regions and the reciprocal relationship between those two things (Mazur \& Sulkowski, 2020). The results of their research show that religious values influence the preferences of the believers and non-believers of the Catholic or Orthodox family. This research assumes that religion is one of the most important factors that affecting organizations. In addition, this research found striking differences in terminal and instrumental values between believers from the Catholic family and non-believers responding from the Catholic family and between Orthodox believers from Orthodox families and unbelievers from Orthodox families. Moreover, social environmental factors also shape the terminal value preference greater than the instrumental value preference in relation to the respondents who declare themselves to be unbelievers, who came from unbelieving families.

The present research is different from the previous studies, which will emphasize the importance of moderate Islamic character education given to the higher education students. Higher education students are the nation's next generation and must be equipped with moderate moral values in order to fill the nation's development with the noble values of the Indonesian nation's religion and culture. Corresponding to this, there are some important issues concerned in this research such as kind of the Islamic character education at university in Indonesia, especially in Indonesia University of Education and the contribution of moderate Islamic character to developed Islamic education in the 4.0 industrial era.

\section{Theoretical Foundations}

\section{Moderate Islamic Character Education}

Character as defined in the Indonesian Dictionary are mental, moral or moral characteristics that distinguish one person from another (Ministry of Education and Culture Indonesia, 2016). 
Meanwhile, someone's character is related to personality which is a trait or characteristic of a person that mostly received from the environments, for instance family,schools, or even innate from birth (Koesoema, 2007). A moral life is led by religion as its main reference. Although religion has many differences regarding what people should do in worship, they all have the same principle that every action they take in life including the choice of moral behavior has a comparable impact in the future. Character itself consists of three things that is moral knowing, moral feeling, and moral behavior (Lickona, 1991). Moreover, good character includes knowledge about goodness, turning into a commitment or intention towards goodness, and finally does goodness. In simple term, character refers to a series of knowledge cognitive, attitude, and motivation as well as behaviors and skills.

Education is one of the important factors in shaping the nation's civilization. It will deliver the changes in the fields of science and technology. Furthermore, education functions to develop the ability and shape the character and civilization of the nation and aims to develop the potentials of the students to become human beings who beliefs and fear of the Almighty God, possess noble characters, healthy, knowledgeable, competent, creative, independent, and become democratic and responsible citizens (Hidayatullah, 2019).

Character education in the Islamic perspective is a form of morality referring to the attributes of the Prophet Muhammad such as "siddiq" or true words and behavior, "amanah" or truly trustworthy not liars, "tabligh" or convey rightness and deter bad acts. Character education carries the same mission as moral education or moral education. The word is derived from the Arabic word "al-akhlaq" which is a plural form of the word "al-khuluq" which means character, temperament, behavior, or habit (Hamzah, 1988).

Based on the above explanation, it can be concluded that moderate Islamic character education is a universal human behavior values that embrace all human activities, both in the context of relating to God, with himself, with other fellow human beings, and with their environments. And this is manifested in thoughts, attitudes, feelings, words, and acts based on religious, legal, and cultural norms, as well as culture and customs.

\section{The 4.0 Industrial Era}

The 4.0 Industry is a trend in the industrial world that combines automation technology with cyber technology. It brings some implications that all developments change rapidly and massively along with technological innovations that at the end will replace human labor. However, Islam teaches dynamism in increasing knowledge and thinking to elevating people of knowledge at a very high level (Hidayatullah, 2019). Challenges and obstacles other than social, natural, technological, economic, political aspects that need to be prepared are knowledge (Zhou et al., 2015). This indicates the importance of educational preparation, especially Islamic education in facing the 4.0 Industrial Revolution.

According to Drath \& Horch (2014), the challenges faced by a nation when implementing policies to support the 4.0 Industrial Revolution are the emergence of resistance to changes in demographics and social aspects, political instability, limited human and natural resources, the risk of natural disasters, and demands for the application of advance technology which is environmentally friendly. It similar that the industrial digital era 4.0., as for the changes made revise the curriculum that is tailored to the development of the community environment; multiply the learning process by strengthening personal skills and building self-confidence; assessment of learning more in the process is not in the form of learning outcomes; and analyzing the results of higher education quality by paying attention to market needs and customer needs and supported by all stakeholders (Subandi, 2019).

\section{The Role of Teachers}

Referring to Castellví (2018) who found that final grade elementary students face many problems about social problems relevant to their time in a coherent, reflective, and critical way. This of course, must be overcome by the training of teachers that follows the principles of critical literacy enabling them to act, be socially committed, and intervene the social problems, and 
develop democratic awareness (Ortega-Sánchez \& Pagès, 2017b). Likewise, the assessment of the importance of didactic treatment of social problems and questions that is socially alive during basic education, in a predictive and prominent way, influences their explicit integration in the social sciences curriculum. The results of the traditional curricular approach in teaching practice hide everyday social problems that confront participatory citizenship. The ultimate goal of teaching history and socialism must lead to the perspectives based on controversial topics, relevant social issues, and social life questions, which are the basis of our daily lives and sustain the development of social competence and citizenship (Hess, 2004; Éthier and Lefrançois, 2008; Heimberg, 2010; Pagès and Santisteban, 2011).

On this case, especially for teacher who teaching Islamic Education, play a big role and responsibility in educating students. This is because teachers are the one who spend most of their time with students (Jaafar, 2018). Therefore, character education will build the moral of students based on ethics and national culture that has been internalized and becomes a special trait of the Indonesian nation. Socially thinking about reality and teaching requires conscious selection and a reflective process of social content that allow teachers to map social problems, and this will be critically reconstructed by students. In practice, this technique will take knowledge gained from everyday contexts, thus providing alternatives, or opening exploration pathways, for solving social problems (creative thinking approaches).

\section{Methodology}

The research method applied is a mixed method with quantitative and qualitative characteristics. Quantitative methods are done through survey methods, namely identifying and describing the characteristics of research subjects in their natural environment. Whereas qualitative methods are used to support and explain quantitative results. According to Cress well and Clark (2011) the benefits of this approach provide a consistent picture and gather information on a limited focus in detail on certain aspects of research. The present research was carried out at the faculty of education and teacher training of Indonesia University of Education. The subjects of this research were followed by graduate students and students in the term of 2016-2017 and term of 2017-2018.

The operational stages of this research are first, interviews, observations, documentation studies, and focus group discussions. Second, data validation by means of triangulation and data cross checking process refers to dimensionality through multiple perspectives and stability (Alwasilah, 2002). Third, analyzing and processing quantitative data. Finally, the data analysis is performed by interpreting the results of focus group discussions, interviews, and observations.

\section{Discussion of Results}

\section{General Courses in Indonesia University of Education}

As the results from the questionnaire which distributed to 70 lecturers who teaching the courses of Pancasila and citizenship education, Islamic religious education, socio-cultural education in the Department of General Education at Indonesia University of Education, obtained data from six samples. The overall sample believes that general education developed by Indonesia University of Education leads to general education aiming at humanizing humans and developing personality.

General education as a middle education, senior high school, includes two phases on the scale of International Education Standard Classification. Middle education level two or lower (less common junior high school) is considered the second and final stage of basic education, and Middle education level three (upper) is the stage before higher education. Each country aims to provide basic education, but the system and terminology remain unique to them. Middle education usually takes place after six years of basic education (elementary school stage) and followed by higher education, vocational education, or employment. Like basic education, in most countries middle education is compulsory, 
at least until the age of 16 years old. Children usually enter the lower secondary phase around the age of 11 years old. Compulsory education sometimes extends to the age of 19 years old.

General education, middle education, and basic education consist of three levels corresponding to the three levels of educational programs such as general, basic general, and secondary general (complete)- the duration of each is 4,2 , and 5 years, respectively. Overall, this successive program takes place11 years (until 12 years in some schools with certain specializations) usually manifested in the same EI, namely secondary public education schools, lyceum, and gymnasia. General basic education (9 years) is compulsory (Filippov \& Tkach, 2010).

In the end of the questionnaire, data demonstrated that the objectives of teaching of compulsory courses consist of: 1. Enable students to have conceptual and procedural knowledge about the values of faith and nationality, have good morals and patriotism (Islamic religious education: being a good human being/moderate Muslim); 2. Value and character education; 3. Providing comprehensive and meaningful courses in internalizing life values in learning; 4. Fostering personality; 5. Becoming a whole human being; 6 . Developing a religious personality, good citizenship, and thinking/being scientific in the frame of the Unitary Republic of Indonesia. A temporary conclusion can be drawn that the teaching objectives of the compulsory courses perceived by the samples have led to the purpose of education in creating good people, not leading to the dominance of cognitive aspects. General education core (general education) must be able to give spirit to the courses contained therein. Citizenship education according to six samples, ideally has the following characteristics: 1 . Providing insight into being a good citizen; 2. As a core in character education; 3. Providing a thorough understanding of good and smart human being; 4. Instilling national values; 5. Civic education means general education; 6. Building four pillars of nationality and good citizenship.

Religious education as a general education must have the following characteristics. First, provide insight and internalization of divine values as the spirit of diversity and religiousness in the Indonesian context; second, understanding and acting in life in harmony with the Qur'an and Hadith, so as to create human beings who have good character; third, smart and interpret all the values of life in accordance to the Qur'an and Hadith; fourth, instilling the values of aqidah, worship, and morals; fifth, religious education which means general education; sixth, build a substantive, peaceful, moderate, and tolerant religiousness, as well as anti-radicalism movement. Meanwhile, the characteristics of Indonesian language education as a general education that distinguishes it from Indonesian language education as study program are: 1 . Providing insight and values of Indonesian language and loving Indonesian language as a national identity; 2. Providing a thorough understanding of using good and right language; 3. Facilitating students to communicate well and correctly; and 4. Build thought patterns and language skills that are good, correct, and polite.

Religious education is GMC which has characteristics such as providing critical thinking ability based on facts, data, and authentic arguments; actualization and implementation of Islamic education values and making students moderate and loving the homeland; directing students to be sensitive to the environment and presenting it with a theoretical foundation based on Islamic values; making students who have broad and comprehensive Islamic insight; making mature human being; build the Islamic mindset that is able to find similarities in differences in religious beliefs and treating Islam as a solution not as a problem. In this context, ideally the GMC is balanced between aspects of aqidah, sharia, and morals; the history of Islamic civilization towards the current development of Islam; material that is contextual to the needs of student life, how GMC in Higher Education, and everything should be ideal.While the characters expected by students after attending the GMC are: 33,3\% answered moderate Muslims; 33,3\% religious; $16,7 \%$ answered adult characters; and $16,7 \%$ the rest replied being a holistic human. The dominant character hoped is good and religious Muslims since the majority of participants filling the questionnaires are coming from the religion education major. Even so, there are answers hoping to be "mature adult" and "holistic human beings" in accordance with the objectives of general education. 
GMC at the Indonesian University of Education is implemented using several approaches including student centered learning, transfer of culture, discovery learning, scientific, whole human development, and argumentative lectures. These approaches support the development of student personality as a whole, with a balance of thought, feeling, and acting.

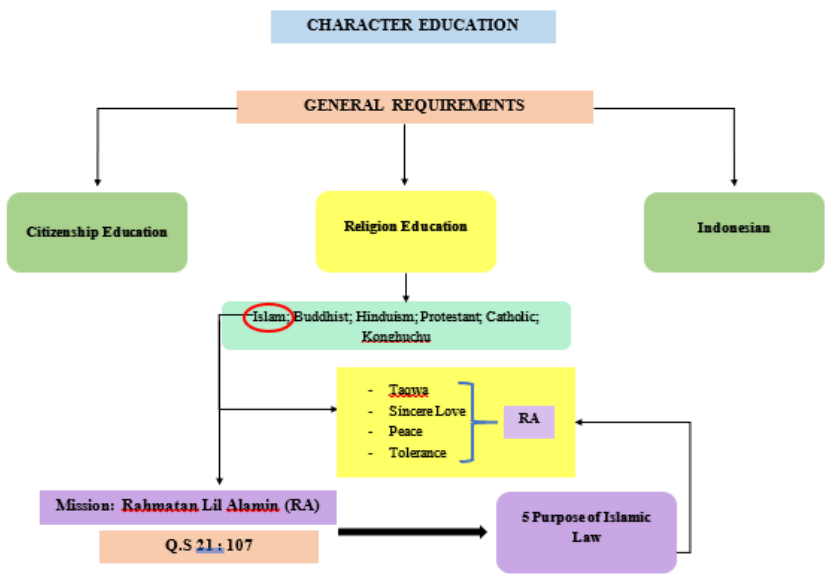

Figure 1. Character Education

\section{Moderate Character Teaching in Islamic Religious Education}

The Indonesian nation consists of various ethnicities, religions, cultures, and languages. Indonesia established by the founding fathers based on Pancasila and Basic Law of 1945 with upholding diversity and determined to be The Unitary State of the Republic of Indonesia. In the same manner, the unity within the university environment in the form of tolerance, loving the homeland, insightful nationality and always ready to defend the country must always be fostered.

In accordance with President Jokowi's "Nawacita" or nine agenda, students and lecturers are strategic agents to build a diverse Indonesia in order to be more advanced and civilized. They are expected to have the ability to think based on high analytic capacity, defending the country, anticorruption, behaving and thinking positively, and have an understand of various global issues. Therefore, they will always be ready to face dynamics and complexity of life. For this reason, learning called general education is necessary held in higher education (Belmawa, 2019).
Students as the main component of the successor of the development of nation need to be equipped with various competencies. It is not only intellectual competence that is characterized by the ability to utilize reason and thought, but also moral competence shown by behaviors that are in harmony with national norms, personality, and identity. Since being smart is not enough, it must also behave and be of good character. Character education or moral is very essential for students. All of that refers to character education or morals originated from divine revelation, hadith of the prophet, as well as the results of ijtihad about the actual problems of the nation.

Islam is a religion that has a vision of monotheism, and the mission of "rahmatan lil'alamin" or grace for the entire universe (Q.S. Al-Anbiya: 107) hence its educational values can be practically internalized in the daily lives of students on campus, and in the community (Purwanto et al., 2019). Islamic education harmonizes the relationship between humans and the Creator, and human relations with other humans. Humans who like to live in harmony, prosperity, tolerance, love to help others, respect human rights, and other noble traits are the goal of the Islamic education. Therefore, moderate Islamic character education based on good moral, as well as national insight is very essential to be given to students at general higher education in the era of 4.0 industry due to the challenges of globalization which is characterized by the increasingly sophisticated information and communication technology. This is in line with the understanding of Islam. The word Islam comes from the root "aslama" meaning to surrender to God. Islam also means salvation, providing safety, and peace for all.

After attending the GMC of Islamic education, students are expected to be: Moderate; Smart, good deeds, gentle heart; Becoming Islamic and Quranic Muslim; Having a good faith towards the God; Religious, especially humble before God and His Messenger; Respect differences, especially the problem of "furuiyah" or differences of idea; Having a strong "aqidah" or creed; Carry out Islamic sharia in an obedient manner; good characters, especially humble, not arrogant; 
Performing praying not merely as a ritual but meaningfulness; Can perform worship well; Having good characters; Having substantive care; Can properly do "muamalah" or relationship; Tolerant towards religious practices and different religious beliefs, and anti-radicalism; Can lead a prosperous family life or "sakinah mawadah warahmah".

As for the GMC of Pancasila and citizenship education, the students are hoped to be more mature in thinking and acting; Have the responsibility to defend religion and the state; Become an Islamic student; Become a whole human being; Not fanatical; Moderate; Be a good citizen; Accept the differences; Think and be scientific; Become a student who can communicate well; Love the homeland; Uphold the 4 pillars of nationality; Become a student who can socialize with the community; "Ukhuwah Islamiyah, jam'iyah, wathaniyah" or tolerant/ moderate; Use good, correct, and polite language both verbally and nonverbally.

At the end, after attending the GMC, the students can possess several mindsets namely receiving a diverse community of religion, culture, language and others related to their role as individual being, God's creatures, and social being. GMC has relationships with other disciplines, has an essential role since it is the base for other subjects, can underlie the disciplines in which it operates, it acts as the ground norm of study programs, it is the spirit of values for the development of other disciplines, as a goal, and as the basis for the Rector to unite faculties through GMC course materials.

GMC actually has a very strategic role in every study program because it has slices, the objectives of learning, in each study program through the 6th level of Indonesian National Qualification Framework that related to the value of general attitudes and skills. Based on the research results $40 \%$ of the respondents said that GMC underlies the study program courses and there are certain study programs that have portion with GMC. These study programs are Natural Education, Arabic Language Education, Pancasila and Citizenship Education, and Sociology Education. While $84 \%$ of the respondents argued that GMC greatly contributed to the character of students, the remaining $16 \%$ did not contribute. $62.2 \%$ of students knew that GMC was a compulsory subject other than the study program courses, and $37 \%$ answered GMC as an important subject to develop student personality. The remaining $0.8 \%$ gives other answers. Therefore, it can be concluded that the students comprehend GMC as a mere formality, not as its objectives. On the other hand, the learning and teaching methods deployed by lecturers in GMC indicated that $58.8 \%$ observation, $47.9 \%$ social interaction, $45.4 \%$ group discussion, $31.9 \%$ social experimentation, problem-based learning $25.2 \%$, research $21.8 \%$, lecture $18.5 \%$, and role playing $17.6 \%$. Based on these findings, it can be assumed that the lecturers have applied contemporary methods, according to the development and needs of the community. Moreover, as a whole, it appears that the lecture technique was less used.

Findings from the results of the questionnaire regarding the characteristics of GMC compared to other courses suggested that it composes of general material $68.1 \%$, many of the lecturers originated from other faculties $42 \%$, normative material content $21 \%$, attended by many students $21 \%$, more relaxed in terms of studying pace $17.6 \%$, and the course mark is easily obtained $3.4 \%$. From these results, it can be inferred that the materials of the GMC have become the major concerns of the students since they are very crucial for the students' lives in the future, its role in teaching the students becoming good human beings and citizens. However, there are still few students who contend that GMC materials are more relaxing and grades are effortless to achieve.

\section{Conclusion}

There are several conclusions drawn from this study. First, character education is the GMC which comprises of several courses namely Religious Education (Islamic), Pancasila and Citizenship Education, and Indonesian Language Education. All the courses aim to develop students' characters.

Secondly, Islamic character education in a general higher education, university, is directed at the development of the character and personality of 
Indonesian people who: 1) Fear of the Almighty God; 2) Having good morals, ethics, and personality when completing their tasks; 3) Being proud of their country and loving the homeland as well as supporting world peace; 4) Able to work together and retaining high social sensitivity and concern for the community and the environment; 5) Respecting for cultural diversity, views, beliefs and religions as well as other people's original opinions/ findings, and; 6) Upholding the rule of law and possessing the spirit to put the interests of the nation and the wider community first and foremost. Furthermore, here are some characters of moderate Islam that must be developed in undergoing the 4.0 Industrial Revolution. First, able to utilize the science, technology, and art in their respective fields of expertise and being able to adapt to the delicate situation and always having the good formula to solve problems. Second, mastering theoretical concepts in a field of knowledge in general and the theoretical concepts of special sections in that field of knowledge in depth, as well as being able to formulate procedural problem solving. Third, able to take strategic decisions based on analysis of information and data and provide instructions in choosing various alternative solutions. Lastly, responsible for their own jobs and having the ability to get responsibility for the achievement of the work of the organization.

\section{References}

[1] ALWASILAH, A. C. 2002. Pokoknya kualitatif: Dasar-dasar merancang dan melakukan penelitian kualitatif. Pustaka Jaya.

[2] BELMAWA. 2019. Panduan program bantuan pengembangan general education.

[3] CASTELLVÍ, J. 2018. La construcción de relatos sobre problemas sociales relevantes locales de alumnos de ciclo superior de Primaria en la era digital. In Buscando formas de enseñar: Investigar para innovar en Didáctica de las Ciencias Sociales. Edited by Esther López, Carmen R. García and María Sánchez. Valladolid: Universidad de Valladolid-AUPDCS, pp. 965-74.
[4] CRESWELL, J., \& CLARK, W. 2011. Designing and conducting mixed methods research. Sage Publication.

[5] DRATH R. \& HORCH A. 2014. Industrie 4.0: Hit or hype (industri forum). IEEE industrial electronics magazine.

[6] ÉTHIER, Marc-André, and LEFRANÇOIS, D. 2008. Investigación sobre el desarrollo de competencias en ciencias sociales a partir de prácticas políticas y comunitarias. ÍBER. DIDÁCTICA DE LAS CIENCIAS SOCIALES, GEOGRAFÍA E HISTORIA, 58, 89-107.

[7] FILIPOV, V.M dan TKACH, G.F. 2010. International Encyclopedia of Education (Third Education) P. 750-757 Elsevier. People's Friendship University of Russia, Moscow, Russian Federation.

[8] HAMZAH, Ya'qub. 1988. Etika Islam: Pembinaan akhlaqulkarimah (suatu pengantar, Cet. IV). CV Diponegoro.

[9] HEIMBERG, C. 2010. ¿Cómo puede orientarse la educación para la ciudadanía hacia la libertad, la responsabilidad y la capacidad de discernimiento de las nuevas generaciones? ÍBER: DIDÁCTICA DE LAS CIENCIAS SOCIALES, GEOGRAFÍA E HISTORIA, 64, 48-57.

[10] HESS, D. E. 2004. Controversies about controversial issues in democratic education. PS: POLITICAL SCIENCE \& POLITICS, 37(2), 257-61.

[11] HIDAYATULLAH， D.S. 2019. Islam pedoman hidup dan kehidupan. Edwrite Publishing.

[12] JAAFAR, Noormajihan. 2018. The validity and reliability of self-efficacy instrument for Islamic education teachers. Opción, Año 34, Especial, No.16, 719745. ISSN 1012-1587/ISSNe: 2477-9385

[13] KOESOEMA, D. A. 2007. Pendidikan karakter: strategi mendidik anak di zaman global (Cet. I.). Grasindo.

[14] LICKONA, T. 1991. Educating for character: How our school can teach respect and responsibility. Bantam books.

[15] MAZUR, B \& SULKOWSKI, L. 2020. Social sciences: Management student values depending on religioncomparative research from Poland. 
[16] MINISTRY OF EDUCATION AND CULTURE INDONESIA. Language Development and Coaching Agency, Ministry of Education and Culture of The Republic of Indonesia: Karakter. 2016. Available at https://kbbi.kemdikbud.go.id/entri/karakter

[17] MUQOWIM, Z. L. 2019. Augmenting science in the Islamic contemporery. ALJĀMI'AH, 57(1), 197-230. doi: 10.14421/ajis.2019.571.197-230

[18] ORTEGA-SÁNCHEZ, Delfin, and PAGÈS, Joan. 2017b. Literacidad crítica, invisibilidad social y género en la formación del profesorado de Educación Primaria. REIDICS. REVISTA DE INVESTIGACIÓN EN DIDÁCTICA DE LAS CIENCIAS SOCIALES, 1, 102-17.

[19] PAGÈS, J. \& SANTISTEBAN, A. 2011. Les qüestions socialment vives $i$ l'ensenyament de les ciències socials. Universitat Autònoma de Barcelona.

[20] PATTARO, C. 2016. Character education: themes and researches. An academic literature reviews. ITALIAN JOURNAL OF SOCIOLOGY OF EDUCATION, 8(1), 6-30. doi: 10.14658/pupj-ijse-2016$1-2$

[21] PURWANTO, et al. 2019. Internalisasi moderasi pendidikan agama islam di perguruan tinggi. Edukasi. Puslitbang Pengda Kemenag.

[22] RIS'AN, Rusli, et.al. 2019. Islamic Moderation in Higher Education. Opcion, Año 35, $N^{\circ}$ 89: 2899-2921. ISSN 10121587/ISSNe: 2477-9385

[23] REPUBLIK INDONESIA. 2003. UndangUndang Republik Nomor 20 Tahun 2003 tentang Sistem Pendidikan Nasional, Cet. 1; Jakarta: BP Panca Usaha.

[24] REPUBLIK INDONESIA. 2012. UndangUndang Republik Nomor 12 Tahun 2012 tentang Pendidikan Tinggi. Available at http://diktis.kemenag.go.id/prodi/dokumen /UU-Nomor-12-Tahun-2012-ttg-

Pendidikan-Tinggi.pdf

[25] SUBANDI, et.al. 2019. Quality of Islamic education management in developing curriculums of industrial era 4.0. Opción,
Año 35, Especial No.21 (2019): 12321247 ISSN 1012-1587/ISSNe: 2477-9385

[26] SYAFEI, et al. 2018. Rekonstruksi kedudukan mata kuliah wajib umum sebagai general education pada tataran implementasi di Departemen Pendidikan Umum UPI. Laporan Riset UPI, Unpublished.

[27] ZHOU, K., TAIGANG L. \& LIFENG Z. 2015. Industry 4.0: Towards future industrial opportunities and challengers, in fuzzy system and knowledge discovery (FSKD), IEEE $12^{\text {th }}$ International Conference. 